\title{
Diagnostic and Prognostic Significance of Serum and Tissue Galectin 3 Expression in Patients with Carcinoma of the Bladder
}

\author{
Hoda El Gendy ${ }^{a} \quad$ Bothina Madkour ${ }^{b} \quad$ Sara Abdelaty ${ }^{b} \quad$ Fayza Essawy $^{b}$ \\ Dina Khattab ${ }^{a}$ Olfat Hammam ${ }^{c}$ Hani H. Nour ${ }^{d}$ \\ aDepartment of Clinical and Chemical Pathology, Ain Shams University, Cairo; Department of ${ }^{b}$ Clinical and Chemical Pathology, \\ cPathology and dUrology, Theodor Bilharz Research Institute, Guiza, Egypt
}

\section{Key Words}

Galectin 3 - Bladder cancer • Transitional cell carcinoma • Squamous cell carcinoma $\cdot$ Schistosomiasis

\begin{abstract}
Background: Galectins are group of proteins found in the cytoplasm, nucleus, cell surface and extracellular matrix. Galectin 3 (Gal-3) displays pathological expression in a variety of processes such as tumorigenesis. Patients and Method: 70 patients classified into the control group, cystitis group, transitional cell carcinoma group, and squamous cell carcinoma group were enrolled in this study which aimed to detect the serum level and the intensity of tissue expression of Gal-3. Results: Both serum level and tissue expression of Gal-3 were statistically higher in bladder cancer patients compared to the other groups. Gal-3 level expression increased from low to high grade urothelial tumors, with a statistically significant increase of its level and expression between muscle invasive and non-muscle invasive Ta urothelial tumors. Conclusion: The serum Gal-3 level is sensitive and specific for the diagnosis of bladder cancer. The prognostic significance of tissue expression is to be confirmed.
\end{abstract}

Copyright $\odot 2013$ S. Karger AG, Basel

\section{KARGER}

Fax +4161306 1234

E-Mail karger@karger.ch

www.karger.com
(C) 2013 S. Karger AG, Basel

1015-9770/13/0074-0185\$38.00/0

Accessible online at:

www.karger.com/cur

\section{Introduction}

Carcinoma of the bladder represents a worldwide health problem ranked ninth in cancer incidence [1]. Several urine and serum tumor markers have been studied for its diagnosis, yet histopathological examination of a transurethrally resected bladder tumor is the corner stone in the diagnosis of bladder cancer allowing both histological diagnosis and tumor staging [2].

Radical cystectomy with urinary diversion is the treatment of choice for muscle invasive (MI) transitional cell carcinoma (TCC) of the bladder, together with other histological types of bladder cancer including squamous cell carcinoma (SCC) which account for about $40 \%$ of bladder cancer in Egypt [3]. It is also the treatment of choice for non-muscle invasive (NMI) TCC refractory to intravesical treatments. The overall tumor free 5-year survival following radical cystectomy (all stages combined) is around $60 \%$ with most of relapses occurring in the first 24 months [4].

Patients' prognosis depends independently on histological type, final pathological stage, and tumor grade. Several tissue markers have been studied to enhance the prognostic accuracy, but the results are conflicting [5].

Galectins are group of proteins identified in the cytoplasm, nucleus, cell surface, and extracellular matrix, which suggest that they have several functions. Studied

Hani H. Nour

Urology Department, Theodor Bilharz Research Institute Guiza (Egypt)

E-Mail hani_nour@hotmail.com 
showed that galectin-3 (Gal-3) plays a role in the regulation of various biological cycles including inflammation, cell growth, cell differentiation, cell adhesion, and apoptosis [6]. Gal-3 displays pathological expression in a variety of process including tumorigenesis e.g. colon and bladder cancer and inflammatory conditions e.g. rheumatoid arthritis, heart disease and stroke [7, 8]. The prognostic significance of Gal-3 expression in several human cancer tissues has been studied with intensity of expression correlating with tumor progression, invasiveness, and metastatic potential [9].

High circulating levels of Gal-3 were also found in the serum of patients with bladder cancer, and these levels correlate with the antiapoptotic activity of Gal-3 as a possible cause of carcinogenesis [10].

The aim of the work was to measure the serum Gal-3 level as well as its expression in bladder tissues of bladder cancer patients, patients with cystitis, and normal individuals. The results will test the potential role of serum Gal-3 in the diagnosis of bladder cancer. In addition, the prognostic significance of Gal-3 expression in different stages and grades of tumor will be evaluated as well as the effect of schistozomal infestation on its expression.

\section{Patients and Method}

This prospective non-randomized study followed the tenets of the Declaration of Helsinki (1975) and had the approval of the ethical committee of Theodor Bilharz Research Institute (TBRI). It included patients with radiologicaly diagnosed bladder growth enlisted for transurethral resection of bladder tumor (TURB) in the Urology Department of TBRI between November 2012 and January 2013, together with patients enlisted for cystoscopy for persistent lower urinary tract symptoms (LUTs). Ten patients served as a control. They had to undergo cystoscopy as a part of their urological workup and/or treatment. The final study included 70 patients, 58 males and 12 females with a median age of 58 years (range $30-84$ years). Patients were divided into the control group $(n=10)$, cystitis group $(n=15), \operatorname{SCC}$ group $(n=10)$, and TCC group (muscle invasive and non-invasive) $(n=35)$. After informed consent, a blood sample was taken from all patients the night before cystoscopy. Transuerethral resection of bladder tumors was done to all patients with an apparent tumor, while cold cup biopsies were taken from bladder mucosa of patients with LUTs and the control group.

Histopathological evaluation was made by an uropathologist in the Pathology Department of TBRI according to the international histological classification of urinary bladder tumors proposed by the WHO in 2004. Immunohistochemical staining, scoring, and interpretation of Gal-3 was done by the same uropathologist. Expression of Gal-3 was evaluated using light microscopy at $400 \mathrm{x}$ magnification and the percentage of the positively stained cells was calculated and scored according to Sakaki et al. [11] as:

- Weak expression (0-20\% stained cells).
- $\quad$ Moderate expression (21-50\% stained cells).

- $\quad$ Strong expression (51-100\% stained cells).

About $2 \mathrm{ml}$ of blood samples were collected under aseptic conditions the night before surgery and were delivered to a plain tube and allowed to clot. Then serum was aliquoted in clean vials and stored frozen at $-20^{\circ} \mathrm{C}$. Enzyme immunoassay technique was used for measurement of serum Gal-3 concentration - ELISA method (eBioscince, Vienna, Austria) [12].

Results were expressed as the median value. Comparison between different parameters in the two groups was done using the Mann-Whitney U test while comparison between the three groups was performed using the Kruskal-Wallis test followed by the Mann-Whitney U test. The Receiver Operating Characteristic (ROC) curve was used to determine the sensitivity and specificity of serum Gal-3. A P value less than 0.05 was considered significant and 0.01 was considered highly significant. Statistical analysis was performed with the aid of the SPSS computer program (version 16 windows).

\section{Results}

The clinicopathological distribution of study groups is showed in table 1 . For an accurate evaluation of the Gal-3 serum level and tissue expression, patients with non-muscle invasive (NMI) TCC were classified according to the depth of invasion into patients with Ta tumors $(\mathrm{n}=6)$ and patients with T1 tumors $(\mathrm{n}=11)$. Associated schistozomal infestation based on the detection of schistozomal eggs in the tissues was present in $40 \%$ of the cases (28/70), 6 in the cystitis group, 7 in SCC group, and 15 in the TCC group.

The median serum Gal-3 level was $100 \mathrm{pg} / \mathrm{ml}$ and 380 $\mathrm{pg} / \mathrm{ml}$ in the control and cystitis groups respectively, with a statistically significant increase in Gal-3 expression in the cystitis group. There were weak tissue expressions of Gal-3 in the control and cystitis groups. Bilharzial infestation did not affect the level or expression of Gal-3 in either the serum or tissue in the cystitis group (table2).

The serum Gal-3 concentration showed a highly significant increase in the TCC and SCC groups when compared to the control and cystitis groups $(\mathrm{p}<0.01)$ with no statistical difference when the TCC group was compared to the SCC group ( $p>0.05)$. There was moderate to strong tissue expression of Gal-3 in all bladder cancer patients either TCC or SCC in relation to the control and cystitis patients, with a significant increase of G3 expression in patients with SCC (fig. 1) in relation to patients with TCC $(p<0.05)$. Schistozomal infestation did not affect the results of serum Gal-3 level in patient with either TCC or SCC, but patients with bilharzial associated SCC showed a highly significant Gal-3 tissue expression in relation to TCC patients. 
Table 1. Clinicopathological distribution

\begin{tabular}{|c|c|c|c|c|}
\hline & Number & Sex & Age, median (range) & Bilharzial infestation, $\%$ \\
\hline Control & 10 & $\mathrm{M}=9, \mathrm{~F}=1$ & $56.5(30-70)$ & $0(0 \%)$ \\
\hline Cystitis & 15 & $\mathrm{M}=12, \mathrm{~F}=3$ & $50(10-80)$ & $6(40 \%)$ \\
\hline $\mathrm{TCC}$ & 35 & $M=29, F=6$ & $60(45-84)$ & $15(42.8 \%)$ \\
\hline NMI & 17 & $\mathrm{M}=14, \mathrm{~F}=3$ & & \\
\hline MI & 18 & $\mathrm{M}=15, \mathrm{~F}=3$ & & \\
\hline High Grade & 18 & $M=16, F=2$ & & \\
\hline Total & 70 & $\mathrm{M}=58, \mathrm{~F}=12$ & $58(30-84)$ & $28(40 \%)$ \\
\hline
\end{tabular}

$\mathrm{M}=$ Male $; \mathrm{F}=$ female $; \mathrm{SCC}=$ squamous cell carcinoma TCC = transitional cell carcinoma NMI = non-muscle invasive; $\mathrm{MI}=$ muscle invasive.

Table 2. Clinicopathological distribution

\begin{tabular}{lccc}
\hline & Number & Gal-3 expression $(\%)$, median (range) & Gal-3 (pg/ml), median (range) \\
\hline Control & 10 & $0(0-10)$ & $100(50-220)$ \\
Cystitis & 15 & $10(0-20)$ & $380(142-1,200)$ \\
SCC & 10 & $80\left(70-90^{\mathrm{a}}\right)$ & $925\left(520-3,200^{\mathrm{ac}}\right)$ \\
TCC & 35 & $55(21-95 \mathrm{a})$ & $720\left(500-4,000^{\mathrm{a}}\right)$ \\
Ta & 6 & $32.5(21-40)$ & $515\left(515-3,120^{\mathrm{a}}\right)$ \\
T1 & 11 & $50\left(40-90^{\mathrm{a}}\right)$ & $1250\left(500-2,080^{\mathrm{a}}\right)$ \\
T2-3 & 18 & $70\left(45-95^{\mathrm{ab}}\right)$ & $840\left(530-4,000^{\mathrm{a}}\right)$ \\
TCC & 35 & $55(21-95)$ & $720(500-4,000)$ \\
Low grade & 18 & $50(21-90)$ & $590(500-3,160)$ \\
High Grade & 17 & $70\left(45-95^{*}\right)$ & $840\left(530-4,000^{*}\right)$
\end{tabular}

${ }^{\mathrm{a}} \mathrm{p}<0.05$ relative to normal urothelium group; ${ }^{\mathrm{b}} \mathrm{p}<0.05$ relative to Ta group; ${ }^{\mathrm{c}} \mathrm{p}<0.05$ relative to TCC; ${ }^{*} \mathrm{p}<0.05=$ significant.

Both serum Gal-3 level and tissue Gal-3 expression were statistically higher in muscle invasive tumors compared to papillary non-invasive tumors $(\mathrm{Ta})(\mathrm{p}<0.05)$, while there was no statistical significance observed between muscle invasive and tumors that invaded subepithelial connective tissue (T1) nor between papillary non-invasive tumors (Ta) and (T1) $(\mathrm{p}>0.05)$. From low to high grade TCC, there was a statistically significant increase in the serum and tissue level of Gal-3 expression $(\mathrm{p}<0.05)$.

ROC curve analysis in order to detect a cutoff serum Gal-3 level in the diagnosis of bladder cancer in relation to normal controls and cystitis patients was applied. The level of serum Gal-3 at cutoff point $\geq 220 \mathrm{pg} / \mathrm{ml}$ provided the best specificity (100\%) for bladder cancer diagnosis in relation to normal urothelium (either TCC or SCC) with $(100 \%)$ sensitivity and (1.00\%) diagnostic accuracy (fig. 2). A cutoff level of $>420 \mathrm{pg} / \mathrm{ml}$ provided a $73 \%$ specificity and $100 \%$ sensitivity (0.957 diagnostic accuracy) for discrimination of bladder cancer patients from patients with cystitis (fig. 3).

\section{Discussion}

In 2010, bladder cancer was responsible for about 170,000 deaths, with more than $55 \%$ of newly diagnosed bladder cancer patients occurring in developed countries 


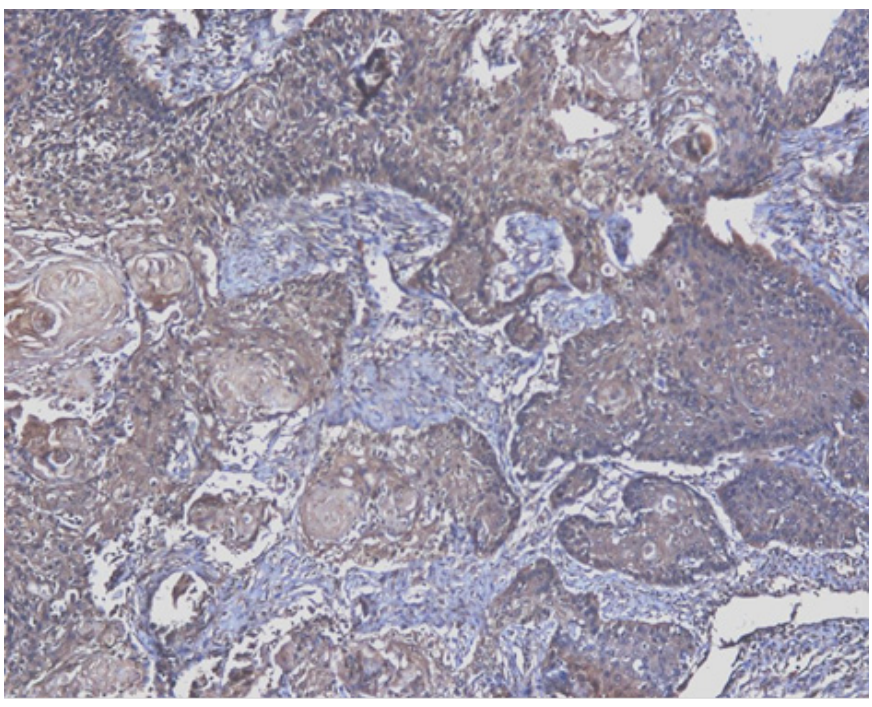

Fig. 1. Poorly differentiated squamous cell carcinoma, GIII, with strong expression of Gal-3 monoclonal antibody (IHC, DAB $\mathrm{x} 200)$.

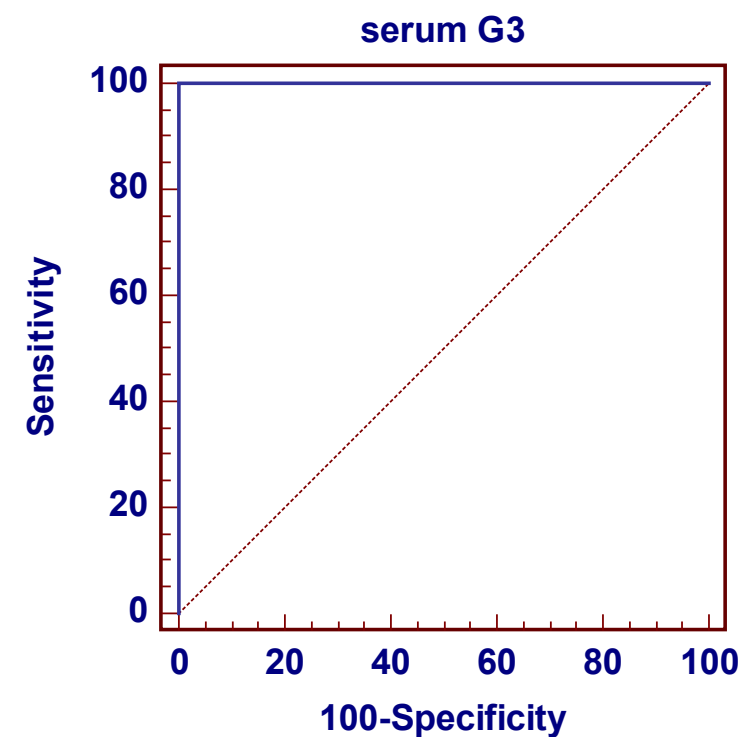

Fig. 2. ROC curve between control and bladder cancer.

[13]. This rate is rapidly changing as bladder cancer is rapidly rising in underdeveloped countries where industrialization has led to carcinogenic exposure [14]. Among the Egyptian population, bladder cancer accounts for $29.8 \%$ of all malignant diseases and it is the most common cancer among males [14].

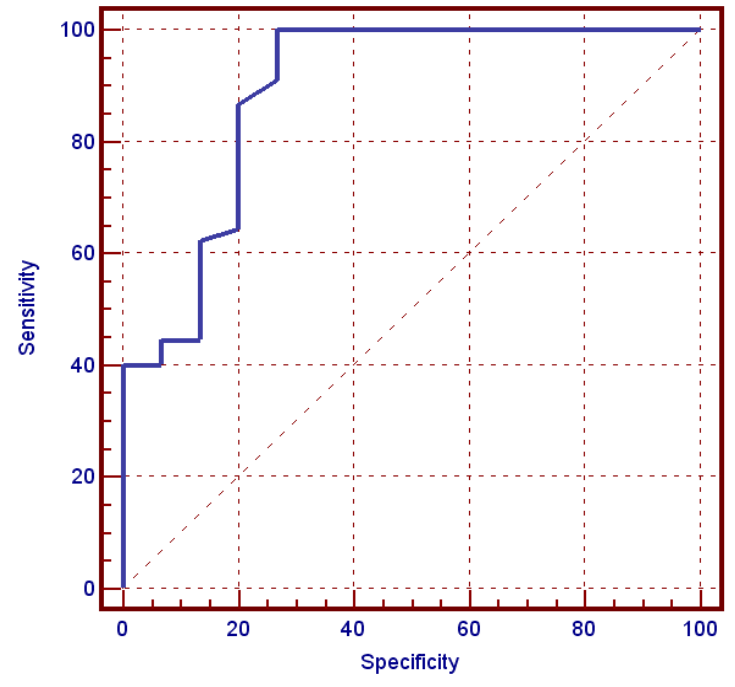

Fig. 3. ROC curve between cystitis and bladder cancer.

In a trial to improve the detection rate of bladder cancer using non-invasive techniques, several tumor markers were studied including detection of urinary bladder tumor antigen (BTA), nuclear matrix protein 22 (NMP22), fluorescence in situ hybridization DNA probe technology, serum carcinoembryonic antigen (CEA), and carbohydrate-antigen 19.9 (CA19.9) [15, 16]. But none of these have taken the place of urine cytology which showed up to $85 \%$ sensitivity and $87 \%$ specificity in high grade tumors [17].

Several tissues markers were tested for their prognostic significance, yet tumor stage and grade together with histological type are still the most reliable prognostic factors upon which patient's prognosis and the need for adjuvant treatment post radical cystectomy depends [5].

Gal-3 is a member of the galactin gene family that is expressed at elevated levels in a variety of neoplastic cell types and has been associated with cell growth, cellular adhesion process, cell proliferation, transformation, metastasis, and apoptosis [18]. It can be expressed in the nucleus, cytoplasm and on the cell surface, and furthermore it can be secreted into the stroma [8]. Gal-3 is involved in the regulation of inflammatory processes through its role in macrophage activation and migration [19].

In this study the serum Gal-3 in bladder cancer patients either TCC or SCC (all stage combined) was statistically higher than in the control group $(p<0.05)$ and cystitis patients $(p<0.05)$, where the median value of 
Gal-3 in serum was $840 \mathrm{pg} / \mathrm{ml}, 100 \mathrm{pg} / \mathrm{ml}$, and $380 \mathrm{pg} / \mathrm{ml}$ in bladder cancer, the control group, and cystitis patients respectively. Schistozomal infestation did not show any statistically significant value. These results confirms the diagnostic utility of serum Gal-3 in patients with bladder cancer as demonstrated by Waalkes et al. [6], who found that patients with a bladder tumor showed an elevated serum level of Gal-3. No statistical difference was found in Gal-3 serum level between TCC and SCC.

Immunohistochemical staining of Gal-3 showed a statistically significant increase of Gal-3 expression in bladder cancer patients (TCC and SCC) in relation to control and cystitis patients $(\mathrm{p}<0.05)$, which confirmed the work of Sakaki et al. [11] , but in his study the effect of urothelial inflammation was not taken into consideration.

Patients with SCC showed a statistically significant higher Gal-3 expression in relation to patients with TCC. This may be attributed to schistozomal infestation which induced an immune response present in approximately $70 \%$ of SCC patients in comparison to only $43 \%$ in TCC patients [20]. The role of Gal-3 in inducing an immune reaction was reported by Sano et al. in 2010 [12].

In 2008, Sakaki et al. [11] reported no significant statistical difference in serum Gal-3 levels in patients with NMI and MI TCC of the bladder. In our study, the serum Gal-3 level and tissue Gal-3 expression were statistically higher in patient with MI TCC in comparison to Ta tumors. However, this significance was lost when comparing MI tumors to tumors invading the lamina proper (T1), and also when comparing T1 to Ta. This may be because that in our study we separately investigated Gal-3 levels and expression in Ta, and $\mathrm{T} 1$ patients, but Kramer et al. [21] were not able to demonstrate a difference in Gal-3 expression between Ta and T1 tumors. We propose 2 hypotheses for this: either these tumors were muscle invasive and we had understaged them, or they represent an aggressive form of $\mathrm{T} 1$. The prognostic significance of Gal-3 expression in T1 tumors must be evaluated as it may help identifying aggressive T1 tumors which may need early radical treatment.

There was a statistically significant increase of serum Gal-3 level and Gal-3 tissue expression from low to high grade TCC of the bladder confirming the results of Canesin et al. [22]. However, Sakaki et al. [11] failed to demonstrate this relation. The present results need to be validated by large scale studies taking into consideration the limitations of the present study to confirm this prognostic significance.

In an attempt to evaluate the diagnostic performance of serum Gal-3 as a diagnostic marker in bladder cancer patients, we found that the level of Gal-3 at a cutoff point of $420 \mathrm{pg} / \mathrm{ml}$ provided the best sensitivity $(100 \%)$ and specificity $(73.3 \%)$ for discriminating bladder cancer patients from patients with cystitis.

This study had several limitations. Although it was prospective, it was a non-randomized study, as it included patient with first time diagnosed bladder cancer we did not study the pattern of Gal-3 level in patients who received intravesical treatment for NMI TCC.

\section{Conclusion}

In our study we evaluated the level of Gal-3 in serum of patients with different types of bladder cancer and compared them to normal individuals. The serum Gal-3 level proved to be as highly sensitive as specific for the diagnosis of both TCC and SCC of the bladder.

Tissue expression of Gal-3 was higher in patients with bladder cancer in relation to normal urothelium. Bilharzial infestation seen more in SCC, may be responsible for the statistically higher expression of Gal-3 in patients with SCC in relation to TCC. As high grade TCC exhibits more Gal-3 tissue expression, its prognostic value needs to be confirmed.

A large scale randomized study needs to be done and it should include a separate group for patients previously treated for NMI bladder cancer. A close follow-up should be given to patients with T1 TCC and high levels of serum Gal-3 as they may be either under-staged or represent an aggressive tumor with high probability of progression. 


\section{References}

-1 Siegel R, Naishadham D, Jemal A: Cancer statistics, 2013. CA Cancer J Clin 2013;63: 11-30.

2 Mitra AP: Urine cytologic analysis: special techniques for bladder cancer detection; in Kumar GL, Kiernan JA (eds): Dako Connection. 2010;14:169-177.

-3 Gouda I, Mokhtar N, Bilal D, El-Bolkainy T, El-Bolkainy N: Bilharziasis and bladder cancer: a time trend analysis of 9843 patients. J Egypt Natl Canc Inst 2007;19:158-162.

-4 Lebret T, Herve JM, Hervé JM, Yonneau L, Barré P, Lugagne PM, Butreau M, Molinié V, Botto H: Study of survival after cystectomy for bladder cancer: Report of 504 cases. Prog Urol 2000;10:553-560.

5 Budman LI, Kassouf W, Steinberg JR: Biomarkers for detection and surveillance of bladder cancer. Can Urol Assoc J 2008;2: 212-221.

-6 Waalkes S, Merseburger AS, Simon A, Serth J, Kuczyk MA: Galectin expression in urological cancer. Diagnostic, prognostic and therapeutic potential. Urologe A 2010;49: 387-391.

7 Takenaka Y, Inohara H, Yoshii T, Oshima K, Nakahara S, Akahani S, Honjo Y, Yamamoto Y, Raz A, Kubo T: Malignant transformation of thyroid follicular cells by galectin-3. Cancer Lett 2003;195:111-119.

-8 Krzeslak A, Lipinska A: Galectin-3 as a multifunctional protein. Cell Mol Biol Lett 2004; 9:305-328.

-9 Nangia-Makker P, Balan V, Raz A: Regulation of tumor progression by extracellular Galectin-3. Cancer Microenviron 2008;1:4351.

10 Balan V, Nangia-Makker P, Raz A: Gelatins as cancer biomarkers. Cancers (Basel) 2010; 2:592-610.

-11 Sakaki M, Oka N, Nakanishi R, Yamaguchi K, Fukumori T, Kanayama HO: Serum level of galectin-3 in human bladder cancer. J Med Invest 2008;55:127-132.

-12 Sano H, Hsu DK, Yu L, Apgar JR, Kuwabara I, Yamanaka T, Hirashima M, Liu FT: Human galectin-3 is a novel chemoattractant for monocytes and macrophages. J Immunol 2000;165:2156-2164.
13 Lozano R, Naghavi M, Foreman K, Lim S, Shibuya K, Aboyans V, Abraham J, Adair T, Aggarwal R, Ahn SY, Alvarado M, Anderson HR, Anderson LM, Andrews KG, Atkinson C, Baddour LM, Barker-Collo S, Bartels DH, Bell ML, Benjamin EJ, Bennett D, Bhalla K, Bikbov B, Bin Abdulhak A, Birbeck G, Blyth F, Bolliger I, Boufous S, Bucello C, Burch M, Burney P, Carapetis J, Chen H, Chou D, Chugh SS, Coffeng LE, Colan SD, Colquhoun S, Colson KE, Condon J, Connor MD, Cooper LT, Corriere M, Cortinovis M, de Vaccaro KC, Couser W, Cowie BC, Criqui MH, Cross M, Dabhadkar KC, Dahodwala N, De Leo D, Degenhardt L, Delossantos A, Denenberg J, Des Jarlais DC, Dharmaratne SD, Dorsey ER, Driscoll T, Duber H, Ebel B, Erwin PJ, Espindola P, Ezzati M, Feigin V, Flaxman AD, Forouzanfar MH, Fowkes FG, Franklin R, Fransen M, Freeman MK, Gabriel SE, Gakidou E, Gaspari F, Gillum RF, Gonzalez-Medina D, Halasa YA, Haring D, Harrison JE, Havmoeller R, Hay RJ, Hoen B, Hotez PJ, Hoy D, Jacobsen KH, James SL, Jasrasaria R, Jayaraman S, Johns N, Karthikeyan G, Kassebaum N, Keren A, Khoo JP, Knowlton LM, Kobusingye O, Koranteng A, Krishnamurthi R, Lipnick M, Lipshultz SE, Ohno SL, Mabweijano J, MacIntyre MF, Mallinger L, March L, Marks GB, Marks R, Matsumori A, Matzopoulos R, Mayosi BM, McAnulty JH, McDermott MM, McGrath J, Mensah GA, Merriman TR, Michaud C, Miller M, Miller TR, Mock C, Mocumbi AO, Mokdad AA, Moran A, Mulholland K, Nair MN, Naldi L, Narayan KM, Nasseri K, Norman P, O'Donnell M, Omer SB, Ortblad K, Osborne R, Ozgediz D, Pahari B, Pandian JD, Rivero AP, Padilla RP, Perez-Ruiz F, Perico N, Phillips D, Pierce K, Pope CA 3rd, Porrini E, Pourmalek F, Raju M, Ranganathan D, Rehm JT, Rein DB, Remuzzi G, Rivara FP, Roberts T, De León FR, Rosenfeld LC, Rushton L, Sacco RL, Salomon JA, Sampson U, Sanman E, Schwebel DC, Segui-Gomez M, Shepard DS, Singh D, Singleton J, Sliwa K, Smith E, Steer A, Taylor JA, Thomas B, Tleyjeh IM, Towbin JA, Truelsen T, Undurraga EA, Venketasubramanian N, Vijayakumar L, Vos T, Wagner GR, Wang M, Wang W, Watt K, Weinstock MA, Weintraub R, Wilkinson JD, Woolf AD, Wulf S, Yeh PH, Yip P, Zabetian A, Zheng ZJ, Lopez AD, Murray CJ, AlMazroa MA, Memish ZA: Global and regional mortality from 235 causes of death for 20 age groups in 1990 and 2010: a systematic analysis for the Global Burden of Disease Study 2010. Lancet 2012;380:2095-2128.
4 Jemal A, Bray F, Center MM, Ferlay J, Ward E, Forman D: Global cancer statistics. CA 15 Cancer J Clin 2011;61:69-90.

Shirodkar SP, Lokeshwar VB: Potential new urinary markers in the early detection of bladder cancer. Curr Opin Urol 2009;19:488-493.

16 Hegele A, Mecklenburg V, Varga Z, Olbert P, Hofmann R, Barth P: CA19.9 and CEA in transitional cell carcinoma of the bladder: serological and immunohistochemical findings. Anticancer Res 2010;30:5195-5200.

17 Moonen PM, Merkx GF, Peelen P, Karthaus HF, Smeets DF, Witjes JA: UroVysion compared with cytology and quantitative cytology in the surveillance of non-muscle-invasive bladder cancer. Eur Urol 2007;51:12751280.

18 Zhang D, Chen ZG, Liu SH, Dong ZQ, Dalin M, Bao SS, Hu YW, Wei FC: Galectin-3 gene silencing inhibits migration and invasion of human tongue cancer cells in vitro via downregulating $\beta$-catenin. Acta Pharmacol Sin 2013;34:176-184.

19 Jiang JX, Chen X, Hsu DK, Baghy K, Serizawa N, Scott F, Takada Y, Takada Y, Fukada H, Chen J, Devaraj S, Adamson R, Liu FT, Török NJ: Galectin-3 modulates phagocytosis-induced stellate cell activation and liver fibrosis in vivo. Am J Physiol Gastrointest Liver Physiol 2012;302:G439-446.

-20 Van den Berg TK, Honing H, Franke N, van Remoortere A, Schiphorst WE, Liu FT, Deelder AM, Cummings RD, Hokke CH, van Die I: LacdiNAc-glycans constitute a parasite pattern for galectin-3-mediated immune recognition. J Immunol 2004;173:1902-1907.

21 Kramer MW, Kuczyk MA, Hennenlotter J, Serth J, Schilling D, Stenzl A, Merseburger AS: Decreased expression of galectin-3 predicts tumour recurrence in pTa bladder cancer. Oncol Rep 2008;20:1403-1408.

22 Canesin G, Gonzalez-Peramato P, Palou J, Urrutia M, Cordón-Cardo C, Sánchez-Carbayo M: Galectin-3 expression is associated with bladder cancer progression and clinical outcome. Tumour Biol 2010;31:277-285. 